\title{
Article \\ Cultivation of Edible Tropical Bolete, Phlebopus spongiosus, in Thailand and Yield Improvement by High-Voltage Pulsed Stimulation
}

\author{
Jaturong Kumla ${ }^{1,2,3, * \mathbb{D}}$, Nakarin Suwannarach ${ }^{1,3} \mathbb{( D )}$ and Saisamorn Lumyong 1,2,3,4 $^{(D)}$ \\ 1 Research Center of Microbial Diversity and Sustainable Utilization, Chiang Mai University, \\ Chiang Mai 50200, Thailand; nakarin.su@cmu.ac.th (N.S.); saisamorn.1@cmu.ac.th (S.L.) \\ 2 Research Group for Renewable Energy, Chiang Mai University, Chiang Mai 50200, Thailand \\ 3 Department of Biology, Faculty of Science, Chiang Mai University, Chiang Mai 50200, Thailand \\ 4 Academy of Science, The Royal Society of Thailand, Bangkok 10300, Thailand \\ * Correspondence: jaturong.kumla@cmu.ac.th; Tel.: +66-87-192-6527
}

check for

updates

Citation: Kumla, J.; Suwannarach, N.; Lumyong, S. Cultivation of Edible Tropical Bolete, Phlebopus spongiosus, in Thailand and Yield Improvement by High-Voltage Pulsed Stimulation. Agronomy 2022, 12, 115. https:// doi.org/10.3390/agronomy12010115

Academic Editors: Koichi Takaki, Nobuya Hayashi, Douyan Wang and Kazunori Koga

Received: 30 November 2021

Accepted: 31 December 2021

Published: 3 January 2022

Publisher's Note: MDPI stays neutral with regard to jurisdictional claims in published maps and institutional affiliations.

Copyright: (C) 2022 by the authors. Licensee MDPI, Basel, Switzerland. This article is an open access article distributed under the terms and conditions of the Creative Commons Attribution (CC BY) license (https:// creativecommons.org/licenses/by/ $4.0 /)$.

\begin{abstract}
Tropical bolete, Phlebopus spongiosus, is an edible ectomycorrhizal mushroom indigenous to northern Thailand. This mushroom has the ability to produce fruiting bodies without the need for a host plant. In this study, the technological cultivation of P. spongiosus was developed. Cultivation experiments indicated that fungal mycelia could completely colonize the cultivation substrate over a period of 85-90 days following inoculation of liquid inoculum. Primordia were induced under lower temperatures, high humidity and a 12-h photoperiod. Mature fruiting bodies were developed from young fruiting bodies within a period of one week. Consequently, yield improvement of $P$. spongiosus cultivation was determined by high-voltage pulsed stimulation. The results indicated that the highest degree of primordial formation, number of mature fruiting bodies and total weight values were obtained in cultivation experiments involving a high voltage of $40 \mathrm{kV}$. The total weight of the mushrooms increased by 1.4 times after applying high-voltage pulses when compared with the control. Additionally, the results revealed that the size of the fruiting body and the proximate composition of the fruiting bodies from high-voltage stimulation treatments were not different from the control. This research provides valuable information concerning successful cultivation techniques and yield improvement by high-voltage pulsed stimulation for the large-scale commercial fruiting body production of $P$. spongiosus.
\end{abstract}

Keywords: bolete; cultivation technique; edible mushroom; high-voltage pulsed stimulation; yield improvement

\section{Introduction}

Edible ectomycorrhizal (ECM) mushrooms have long been consumed as a functional food but have also been used for medicinal purposes [1-4]. These mushrooms have been defined as a seasonal and highly priced crop for which the production yield is based on the climatic conditions of each year. A significant increase in the consumer demand of edible ECM mushrooms has led to their elevated value on the global market [1,5]. Botetus edulis (king boletes), Cantharellus spp. (chanterelles), Morchella spp. (morels), Tricholoma matsutake (matsutake) and Tuber spp. (truffles) are known to be the most expensive edible ECM mushrooms in the world [2,5-7]. The requirements involving essential nutrients, host plant associations and the particular conditions for fruiting body production are the primary problems associated with the successful cultivation of ECM mushrooms. Additionally, some of these mushrooms may rely on a specific species of host plant [2,6-9]. Cultivation of effective fruiting body production for some ECM mushrooms (chanterelles, king boletes, matsutake and truffles) have been established with these host plants [1,2,6]. However, only a few ECM mushroom species have the ability to produce fruiting bodies without 
the need for a host plant when cultivated in a suitable substrate under specific growth conditions [10-13].

The tropical bolete known as Phlebopus spongiosus is an edible ECM mushroom that is indigenous to northern Thailand and southern Vietnam [14-17]. This bolete is a highly priced crop (5 to $10 \mathrm{USD} / \mathrm{kg}$ ) in northern Thailand. Phlebopus spongiosus produces fruiting bodies in natural habitats during the months of May to July (the end of the hot season to the onset of the early rainy season) and sometimes in October (the end of the rainy season) of each year [14]. Thus, this mushroom can typically be collected for consumption from natural habitats during one or two specific periods of time each year. It produces large fruiting bodies and a texture that is similar to the king bolete (Boletus edulis), which is also a popular edible marketable bolete in Europe. In nature, certain fruit trees namely, Citrus maxima (pomelo), Dimocarpus longan (longan) and Mangifera indica (mango), are known to form an ectomycorrhizal association with this mushroom [14,16,17]. Most Phlebopus species are considered delicacies with potentially high commercial value in many countries in Asia and South America $[2,4,14,16-20]$. The Phlebopus species can be isolated and cultured in artificial media; thus, their potential to produce fruiting bodies without a host plant is reliant upon their saprophytic lifestyle $[17,21-23]$. To date, only P. portentosus have been successfully produced on a commercial scale without host plants in China [19]. Recently, our previous study has demonstrated that P. spongiosus is a second Phlebopus species that it has the potential to produce mature fruiting bodies without a host plant in greenhouses [14] However, the relevant mushroom cultivation technology for high-production yields would still require improvement. Several previous studies have demonstrated that the suitable cultivation method and substrate, as well as the appropriate nutritional supplementation, electric stimulation, and application of different wavelengths of light could improve yield of various mushrooms, e.g., Agaricus spp. (button mushrooms), Flammulina velutipes (golden needle mushroom), Pholiota nameko (nameko), Pleurotus spp. (oyster mushrooms) and Lentinula edodes (shitake) [24-28]. Therefore, this study developed effective cultivation techniques and protocols of $P$. spongiosus in the absence of host plants. Moreover, the electrical stimulation delivered by a high-voltage pulsed power generator was applied to modify the cultivation techniques for improved yields of this mushroom. The results of this study can provide valuable information for the commercial cultivation of this mushroom in the absence of a host plant. Moreover, our findings could further enhance relevant strategies for yield improvement of this mushroom using high-voltage pulsed stimulation.

\section{Materials and Methods}

\subsection{Fungal Strains}

A pure culture of P. spongiosus strain SDBR-CMU0517 [14] was selected and used in this study. This fungus was obtained from the Culture Collection of the Sustainable Development of Biological Resources Laboratory (SDBR), Department of Biology, Faculty of Science, Chiang Mai University, Thailand. Fungal culture was maintained in $20 \%$ glycerol at $-20^{\circ} \mathrm{C}$. From this stock culture, a new culture was reactivated on L-MMN agar [29] and incubated at $30^{\circ} \mathrm{C}$ for two weeks in the dark.

\subsection{Fungal Inoculum Preparation}

Liquid inoculum was used in this study. Fungal inoculum was conducted in 500-mL Erlenmeyer flasks containing $200 \mathrm{~mL}$ of L-MMN liquid medium (pH 5.0) [29]. Ten fungal mycelial plugs ( $5 \mathrm{~mm}$ in diameter) obtained from a colony growing on L-MMN agar at $30^{\circ} \mathrm{C}$ for two weeks were transferred into Erlenmeyer flasks after being autoclaved at $121{ }^{\circ} \mathrm{C}$ for $15 \mathrm{~min}$. Cultivation was performed on an orbital shaker with shaking at $120 \mathrm{rpm}$ at $30^{\circ} \mathrm{C}$ in the dark. After three weeks of incubation, liquid culture was used as an inoculum (Figure 1A). 

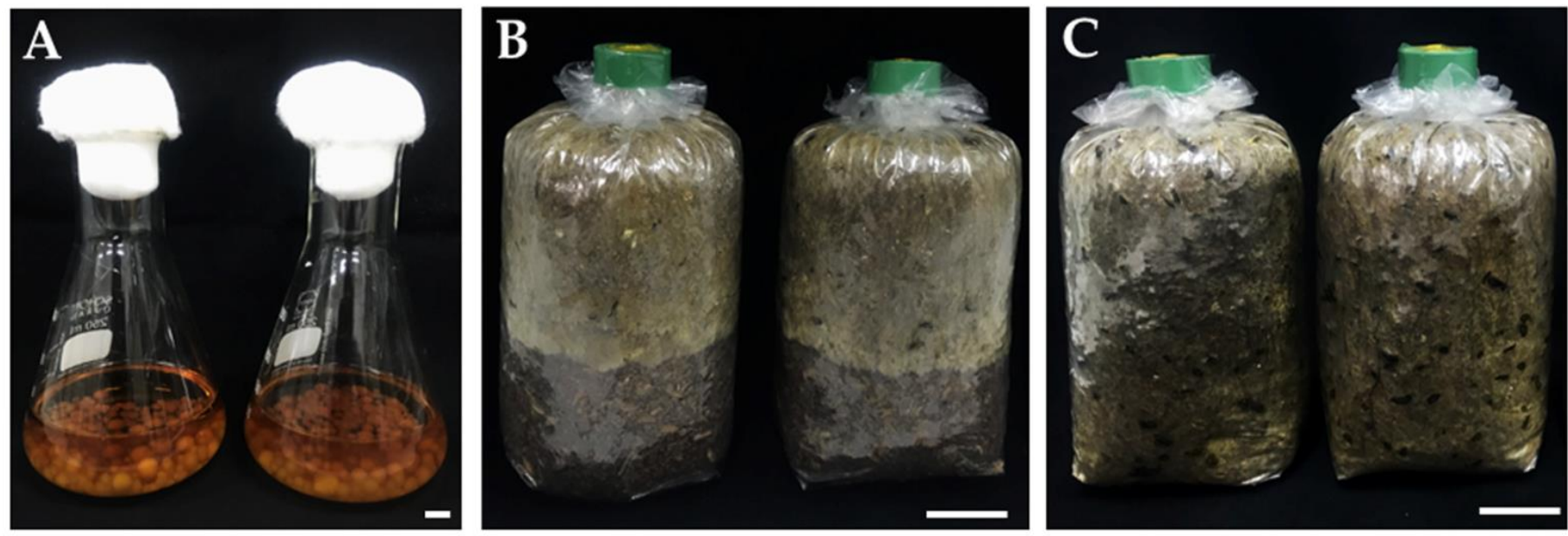

Figure 1. Mycelium liquid inoculum of P. spongiosus SDBR-CMU0517 (A) and mycelia grow on substrate after 60 days (B) and 90 days (C) at $28 \pm 2{ }^{\circ} \mathrm{C}$ in the dark after inoculation of liquid inoculum. Scale bar $\mathrm{A}=1 \mathrm{~cm}, \mathrm{~B}$ and $\mathrm{C}=5 \mathrm{~cm}$.

\subsection{Substrate Preparation and Fungal Inoculation}

Bag cultivation was employed in this study. The sawdust of a rubber tree (Hevea brasiliensis) mixed with rice seed (Oryza sativa) at a ratio of 2:1 $(w / w)$ was used as a cultivation substrate. Subsequently, $0.5 \%$ calcium carbonate $\left(\mathrm{CaCO}_{3}\right), 0.25 \%$ epsom salts $\left(\mathrm{MgSO}_{4}\right)$ and $0.05 \%$ potassium dihydrogen orthophosphate $\left(\mathrm{KH}_{2} \mathrm{PO}_{4}\right)$ were added to the substrate mixture on a dry weight basis. The moisture content of the substrate mixture was adjusted with water at $70 \pm 2 \%$ on a wet basis. After adjusting for moisture content, $800 \mathrm{~g}$ of the substrate mixture was deposited in polypropylene bags $(16.50 \mathrm{~cm}$ wide and $31.75 \mathrm{~cm}$ long). Bags were then plugged with polyvinyl chloride pipe rings and sealed with cotton. Bags were sterilized by being autoclaved at $121^{\circ} \mathrm{C}$ for $1 \mathrm{~h}$ and allowed to cool at room temperature $\left(28 \pm 2{ }^{\circ} \mathrm{C}\right)$ for $24 \mathrm{~h}$ before mycelial inoculation.

Fifteen milliliters of liquid inoculum were added to each sterilized bag containing the cultivation substrate by aseptic inoculation. The inoculated bags were then incubated at $28 \pm 2{ }^{\circ} \mathrm{C}$ in the dark. The fungal mycelia completely covered the substrate after 85-90 days of incubation (Figure 1B,C). Bags were subsequently transferred into the cropping room for fruiting body production.

\subsection{Fruiting Body Production}

Bags were incubated in a cropping room at $25 \pm 2{ }^{\circ} \mathrm{C}$ and a $12 \mathrm{~h}$ photoperiod by fluorescent lamp (light intensity of 1500-2000 lux). The relative humidity was set at $80 \%$ using a humidifier (CAREL HumiDisk 65, Turin, Italy), while a table fan allowed for cross-ventilation. The room was disinfected with $10 \%$ formaldehyde prior to initiating the experiment. Bags were cased with $300 \mathrm{~g}$ of sterilized soil ( $\mathrm{pH}$ 6.5-6.8, saturated with water) at approximately $4-5 \mathrm{~cm}$ height and placed on an aluminum shelf. The relevant periods of time for both primordial formation and fruiting body formation were observed. The average numbers of primordia of each bag were counted and recorded. Mature fruiting bodies were harvested and immediately weighed. The size of the mature fruiting bodies was also measured.

\subsection{Yield Improvement by High-Voltage Pulsed Stimulation}

\subsubsection{Pulsed Power Generator}

A high-voltage pulsed power generator (Figure 2A) was used in this study according to the method described by Takahashi et al. [25] with a Cockcroft-Walton circuit (GM100; Green techno, Kanagawa, Japan). The pulsed power generator was employed to generate high voltage DC from AC $100 \mathrm{~V}$ plug power. 

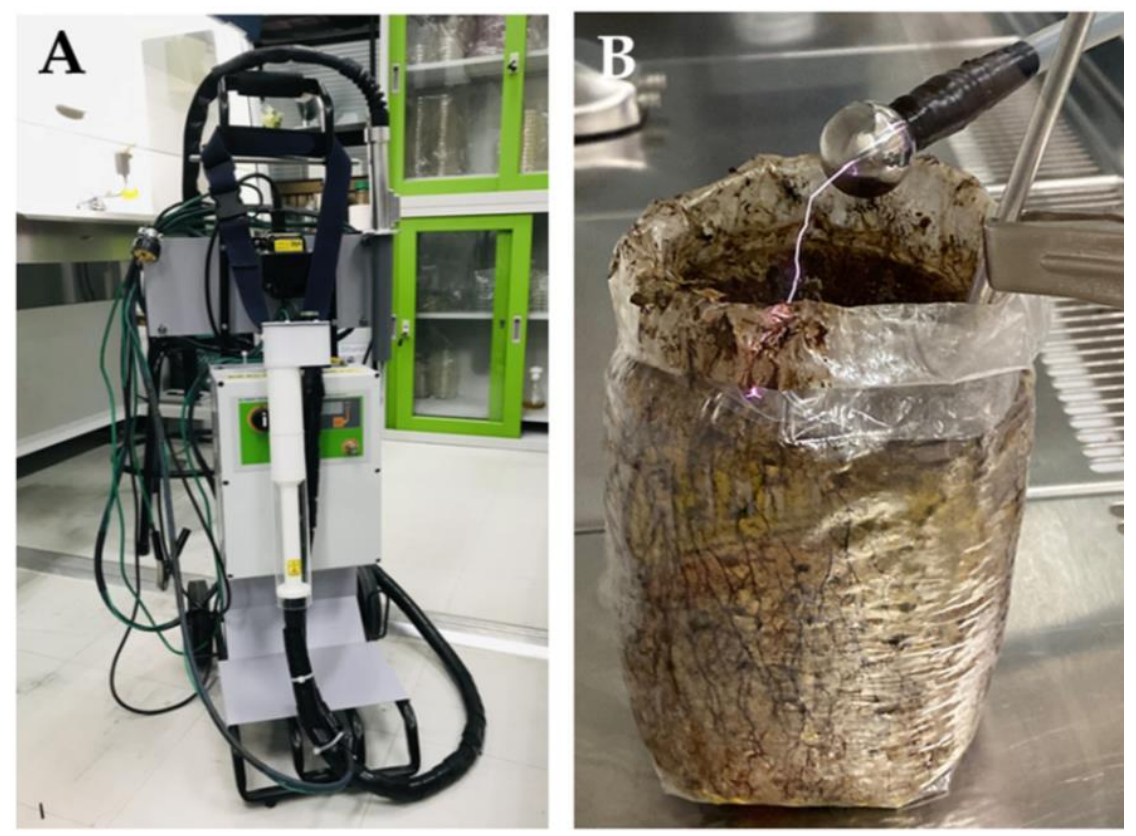

Figure 2. A high-voltage pulsed power generator (A) and the application of high-voltage pulses on the mushroom bag (B).

\subsubsection{High-Voltage Pulsed Stimulation}

Bags that had the substrate completely covered with fungal mycelia were used in this experiment. The application of high-voltage pulsed stimulation on mushroom production in this study was accomplished according to the procedure described by Takahashi et al. [25] with some modifications. Briefly, each mushroom bag was placed in a laminar cabinet. An aluminum needle that was $3 \mathrm{~mm}$ in diameter was driven into the mushroom bag to a depth of $8 \mathrm{~cm}$. The aluminum needle was connected to an earth lead power supply as is shown in Figure 2B. This experiment was divided into a total of six treatments, as indicated in Table 1. Five treatments were stimulated by pulsed voltage at $10 \mathrm{~s}$ with different amounts of high-voltage pulses. The remaining treatment was considered a control. After application of high-voltage pulses, bags were cased with soil and placed on a shelf in the cropping room under the conditions described above. The numbers of primordia and mature fruiting bodies of each bag were counted and recorded. The weight and size of the mature fruiting bodies were measured. The average numbers of primordia and mature fruiting bodies per bag, and the average weight of each fresh fruiting body per bag, were then calculated. Subsequently, the total weight of the fresh fruiting bodies in each treatment was calculated. Thirty replications were carried out in each treatment with two independent runs.

Table 1. Treatment details of this study.

\begin{tabular}{cc}
\hline Treatment Name & Treatment Details \\
\hline $0 \mathrm{kV}$ & Control (non-high-voltage pulsed application) \\
$20 \mathrm{kV}$ & Application of $20 \mathrm{kV}$ high-voltage pulse with $10 \mathrm{~s}$ \\
$40 \mathrm{kV}$ & Application of $40 \mathrm{kV}$ high-voltage pulse with $10 \mathrm{~s}$ \\
$60 \mathrm{kV}$ & Application of $60 \mathrm{kV}$ high-voltage pulse with $10 \mathrm{~s}$ \\
$80 \mathrm{kV}$ & Application of $80 \mathrm{kV}$ high-voltage pulse with $10 \mathrm{~s}$ \\
$100 \mathrm{kV}$ & Application of $100 \mathrm{kV}$ high-voltage pulse with $10 \mathrm{~s}$ \\
\hline
\end{tabular}

\subsection{Proximate Composition Analysis}

The proximate composition (ash, carbohydrate, fat, fiber, and protein) of the mushroom samples from each treatment was investigated according to the method established by the Association of Official Analytical Chemists (AOAC) [30] at the Central Laboratory 
(Chiang Mai, Thailand) Company Limited (Chiang Mai, Thailand). Five replications were performed for each treatment.

\subsection{Statistical Analysis}

One-way analysis of variance (ANOVA) was applied to compare mean values using the statistical program SPSS program version 23.0 for Microsoft Windows 10. Significant differences between treatments were indicated by Tukey's test at the $p \leq 0.05$ level.

\section{Results and Discussion}

\subsection{Fruiting Body Production and Yield Improvement by High-Voltage Pulsed Stimulation}

After 85-90 days of incubation, fungal mycelia completely covered the substrate, and bags were transferred to the cropping room (Figure 3). Use of the casing method, in combination with conditions of low temperature and high humidity, were necessary to induce the primordia formation of $P$. spongiosus [14]. Similarly, previous studies have reported that primordia formation of Agaricus bisporus [31], A. subufescens [32], P. portentosus [13,22,33,34] and Stropharia rugosoannulata [35] required a casing step. Under specified conditions in the cropping room, yellow to yellow-brown primordia formed after 10-15 days of incubation and subsequently developed to young fruiting bodies (Figure 4A-C). Young fruiting bodies then completely developed into mature fruiting bodies within one week (Figure 4D,E). However, only one or two young fruiting bodies developed to a fully mature stage. From each bag, we obtained one or two mature fruiting bodies. This outcome was similar to the findings of previous studies, which reported that the number of mature fruiting bodies obtained from the cultivation of $P$. portentosus under the absence of host plant conditions ranged from one to two fruiting bodies per bag $[13,33,34]$. In our study, caps of mature fruiting bodies were $6.5-10.5 \mathrm{~cm}$ in diameter, and the stipes were $6.00-9.50 \mathrm{~cm}$ high and $3.00-4.50 \mathrm{~cm}$ wide. The weight of each mature fruiting body was observed to be within the range of 30.28 to $60.45 \mathrm{~g}$.
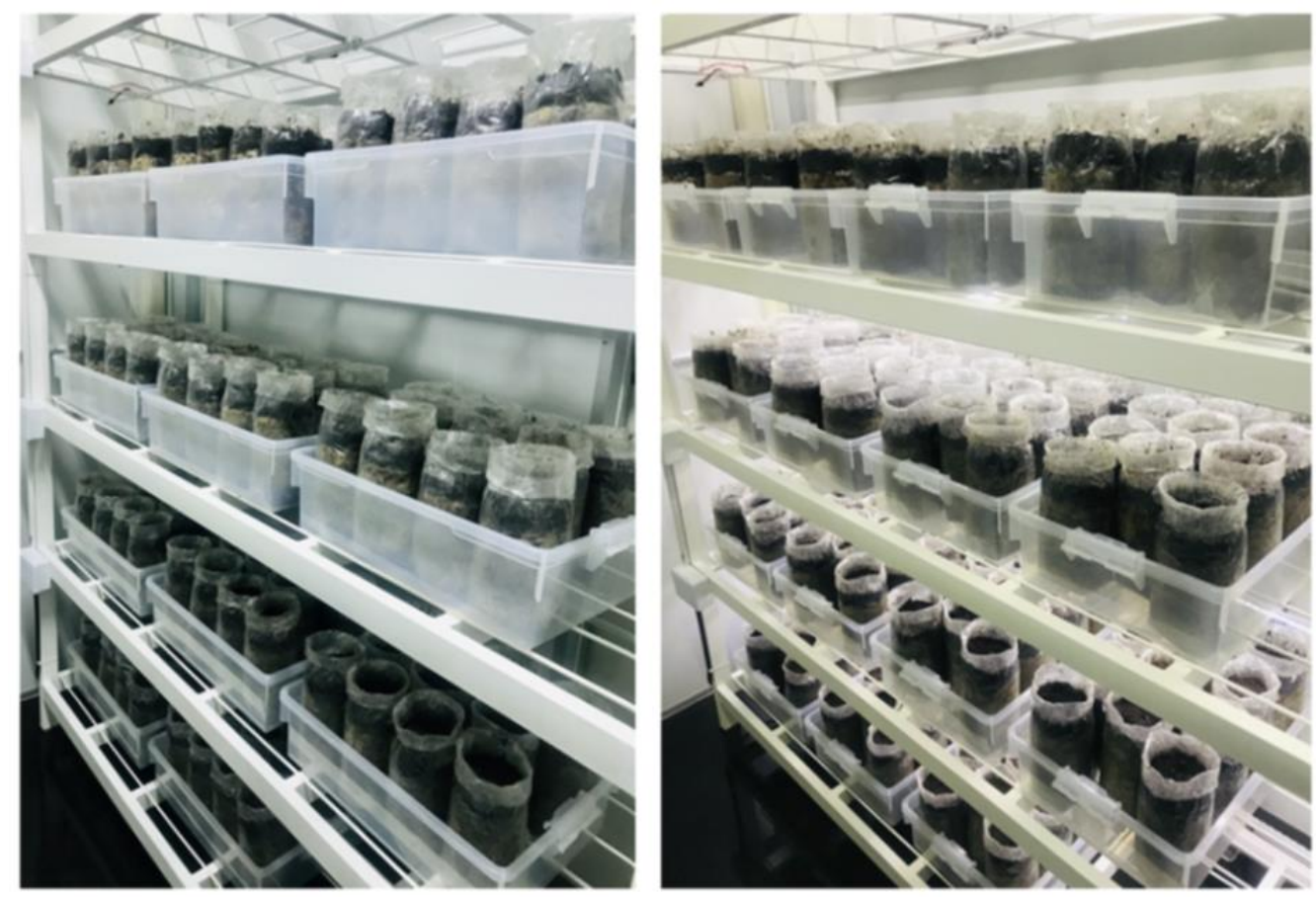

Figure 3. Cultivation of P. spongiosus in the cropping room. 

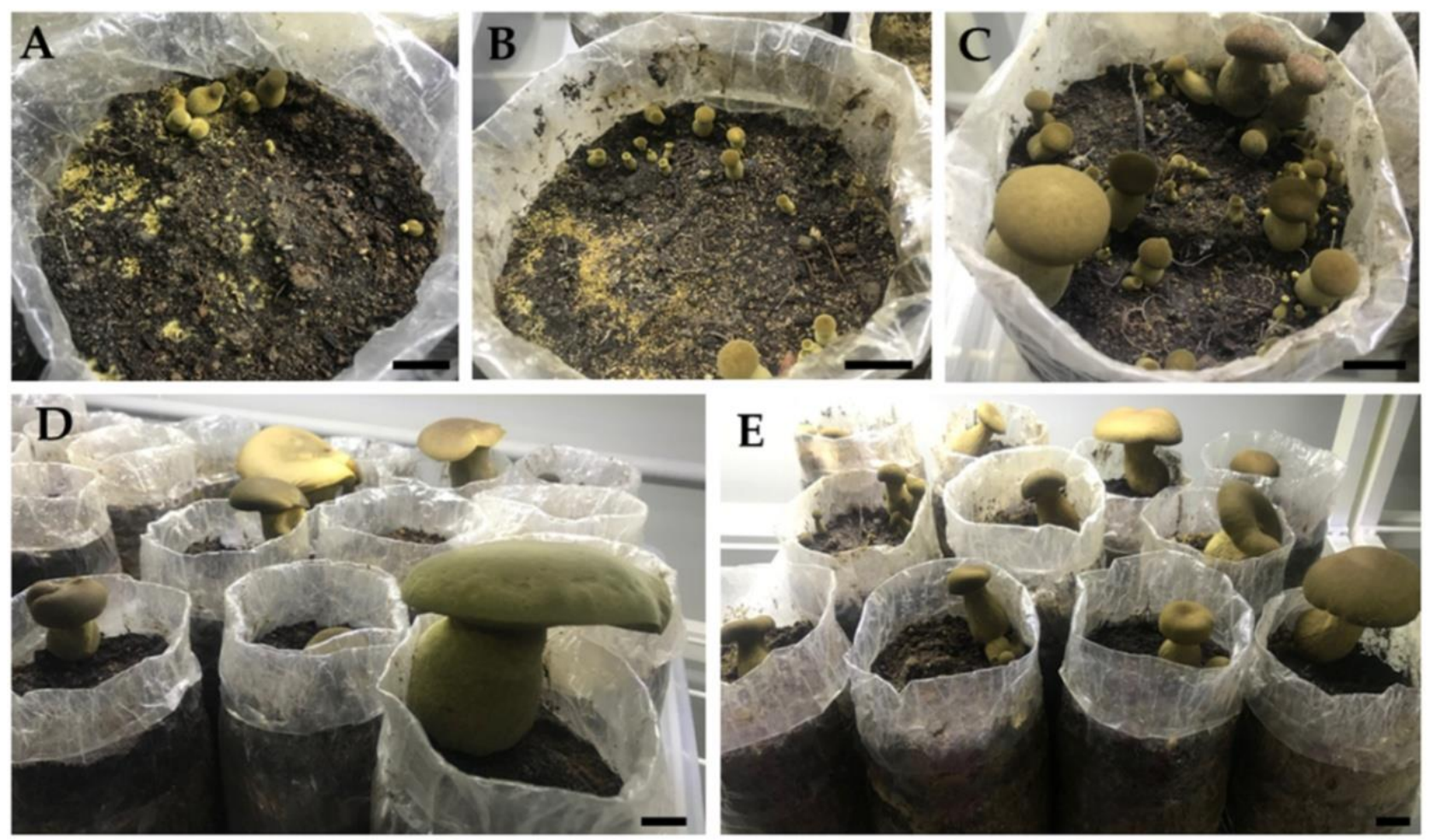

Figure 4. Fruiting body production of P. spongiosus in cropping room. Primordial formation after 10-15 days of incubation (A,B). Primordia develop to young fruiting bodies (C). Yong fruiting bodies develop to mature fruiting bodies within one week $(\mathbf{D}, \mathbf{E})$. Scale bar $=1 \mathrm{~cm}$.

In this study, five different voltage values of 20, 40, 60, 80 and $100 \mathrm{kV}$ with $10 \mathrm{~s}$ for each voltage amount were administered to improve $P$. spongiosus cultivation. The results indicated that the application of high-voltage pulses did effectively influence the cultivation of this mushroom. It was found that the average number of primordial formations of each bag increased when high-voltage pulse values of 20 and $40 \mathrm{kV}$ were applied, but decreased after values of 60,80 and $100 \mathrm{kV}$ were applied. Remarkably, the application of $40 \mathrm{kV}$ was the optimum amount of voltage that resulted in the highest average number of mature fruiting bodies per bag, highest average weight of each fresh fruiting body per bag and the highest total fresh weight of the fruiting bodies (Table 2). Interestingly, the total fresh weight of the mushrooms increased by 1.4 times after the application of $40 \mathrm{kV}$. It was found that the application of high-voltage pulses had no effect on the size of the fruiting body when compared with the control (Table 3). Our results were similar to those of previous studies which had reported that the application of high-voltage pulses could improve mushroom cultivation yields $[25,26,36]$. However, the optimal value of stimulated voltage was dependent upon mushroom species and time. For example, Takaki et al. [25] found that applying a voltage of $50 \mathrm{kV} 5$ times and $300 \mathrm{kV} 500$ times could improve the cultivation yields of shitake mushrooms (L. edodes) via log cultivation and the cultivation yields of a fried chicken mushrooms (Lyophyllum decastes) via bed cultivation, respectively. The highest yield of nameko (Pholiota nameko) and chestnut (Hypholoma sublateritium) mushrooms by log cultivation was observed when a high-voltage pulse at $100 \mathrm{kV}$ was applied a single time [37]. Additionally, Norarat et al. [38] found that the application of high-voltage pulse values of 20, 30, 40 and $50 \mathrm{kV}$ for $10 \mathrm{~s}$ could improve cultivation yields of shitake mushrooms by bag cultivation, while the production yields at each voltage value were not found to be significantly different. However, these cultivation yields were significantly higher than for the control (non-voltage stimulation). Furthermore, Isalam and Ohga [39] found that the application of high-voltage pulses on field plots in pine forests could increase the quality and quantity of matsutake (T. matsutake) mushroom production. 
Table 2. Cultivation of P. spongiosus and high-voltage pulsed stimulation.

\begin{tabular}{|c|c|c|c|c|}
\hline \multirow[b]{2}{*}{ Treatment Name } & \multicolumn{4}{|c|}{ Parameter * } \\
\hline & $\begin{array}{l}\text { Average Number of } \\
\text { Primordia per Bag }\end{array}$ & $\begin{array}{c}\text { Average Number of } \\
\text { Mature Fruiting } \\
\text { Bodies per Bag }\end{array}$ & $\begin{array}{c}\text { Average Weight of } \\
\text { Each Fresh Fruiting } \\
\text { Body per Bag (g) }\end{array}$ & $\begin{array}{l}\text { Total Weight of Fresh } \\
\text { Fruiting Bodies (g) }\end{array}$ \\
\hline $0 \mathrm{kV}$ & $17.13 \pm 2.89 c$ & $1.28 \pm 0.41 b$ & $38.98 \pm 6.71 b$ & 1364.24 \\
\hline $20 \mathrm{kV}$ & $21.87 \pm 2.93 \mathrm{ab}$ & $1.27 \pm 0.52 \mathrm{ab}$ & $41.73 \pm 7.28 \mathrm{ab}$ & 1585.75 \\
\hline $40 \mathrm{kV}$ & $24.50 \pm 3.02 \mathrm{a}$ & $1.47 \pm 0.63 \mathrm{a}$ & $44.14 \pm 6.58 \mathrm{a}$ & 1898.21 \\
\hline $60 \mathrm{kV}$ & $18.63 \pm 2.29 b$ & $1.17 \pm 0.38 b$ & $39.57 \pm 6.39 b$ & 1385.09 \\
\hline $80 \mathrm{kV}$ & $16.53 \pm 1.80 \mathrm{~d}$ & $1.10 \pm 0.40 \mathrm{~b}$ & $38.62 \pm 6.39 b$ & 1274.30 \\
\hline $100 \mathrm{kV}$ & $15.50 \pm 2.11 \mathrm{~d}$ & $1.06 \pm 0.25 b$ & $38.78 \pm 5.29 b$ & 1241.05 \\
\hline
\end{tabular}
different according to Tukey's test $(p \leq 0.05)$.

Table 3. Fruiting body size of $P$. spongiosus resulting from the cultivation process and high-voltage pulsed stimulation.

\begin{tabular}{cccc}
\hline \multirow{2}{*}{ Treatment Name } & & \multicolumn{2}{c}{ Size of Cultivated Fruiting Body * } \\
\cline { 2 - 4 } & Cap Diameter $\mathbf{c m})$ & Height (cm) & Stipe \\
\cline { 2 - 4 } & & $7.89 \pm 1.19 \mathrm{a}$ & $3.63 \pm 0.42 \mathrm{a}$ \\
\hline $0 \mathrm{kV}$ & $8.07 \pm 2.43 \mathrm{a}$ & $7.75 \pm 1.09 \mathrm{a}$ & $3.64 \pm 0.54 \mathrm{a}$ \\
$40 \mathrm{kV}$ & $8.06 \pm 2.27 \mathrm{a}$ & $7.83 \pm 1.23 \mathrm{a}$ & $3.66 \pm 0.61 \mathrm{a}$ \\
$60 \mathrm{kV}$ & $8.11 \pm 2.44 \mathrm{a}$ & $7.73 \pm 1.18 \mathrm{a}$ & $3.70 \pm 0.56 \mathrm{a}$ \\
$80 \mathrm{kV}$ & $8.00 \pm 2.57 \mathrm{a}$ & $7.79 \pm 1.68 \mathrm{a}$ & $3.66 \pm 0.52 \mathrm{a}$ \\
$100 \mathrm{kV}$ & $7.96 \pm 2.64 \mathrm{a}$ & $7.74 \pm 1.05 \mathrm{a}$ & $3.67 \pm 0.41 \mathrm{a}$ \\
\hline
\end{tabular}

${ }^{*}$ The results are mean \pm standard deviation. Different letters in the same column are considered significantly different according to Tukey's test $(p \leq 0.05)$.

The mechanisms of high-voltage pulsed stimulation that drive increases in fruiting body formation are not yet fully understood. However, two possible mechanisms have been explained in some previous studies [40-44]. One is that the mushroom mycelia were ruptured by the application of high-voltage pulses, and that physical damage to the mycelia could stimulate fruiting body formation [37,41-43]. Another viable explanation would involve the act of enzyme activation. Some enzymes are activated by applying a high-voltage pulse, and consequently, mushroom fruiting bodies may develop abundantly [40,43,44].

\subsection{Proximate Composition Analysis}

The amounts of ash, carbohydrate, protein, fat, and fiber of the fruiting bodies obtained from each treatment are shown in Table 4 . The results indicate that applications of highvoltage pulses did not cause significant changes in the ash, carbohydrate, protein, fat, and fiber contents when compared with the control. Thus, the application of high-voltage pulsed stimulation had no effect on the proximate composition of the obtained fruiting bodies. Importantly, this is the first report on the nutrition value of the fruiting body of $P$. spongiosus after cultivation in the absence of host plant conditions and application of high-voltage pulse. Additionally, the amounts of the proximate composition in the cultivated fruiting body were compared with those of the fruiting body collected from natural habitats. It was found that protein and fiber contents observed in the fruiting bodies obtained from the cultivation process were significantly lower than in the fruiting bodies collected from the natural habitat (Table 4). Carbohydrate content in cultivated mushrooms was significantly higher than in natural mushrooms. This could be explained by the fact that $P$. spongiosus grown in natural habitats is known to be an ECM fungus that receives carbon and nitrogen from plants and soil, respectively. However, $P$. spongiosus cultivated with use of the bag process has been identified as a saprotrophic-like fungus. The protein and carbohydrate content in the fruiting bodies of $P$. spongiosus grown in 
natural habitats may be linked to the high amounts of available nitrogen (ammonium, nitrate and organic nitrogen) obtained from sources in the soil and low amounts of carbon received from plant sources when compared with the cultivation substrate. This would likely have occurred because the cultivation substrate may have contained low amounts of nitrogen and high amounts of carbon. These results are supported by the findings of previous studies, which had reported that the amount and type of available nitrogen and carbon minerals in the growing substrate, and the ability to take up nitrogen and carbon minerals of the mushrooms, were significantly affected in terms of the nutrient composition of the mushrooms, especially in terms of the protein and carbohydrate contents $[35,45-47]$. Moreover, Kumla et al. [48] found that cultivated P. portentosus possessed lower protein and higher carbohydrate contents than P. portentosus collected from natural habitats.

Table 4. Proximate composition on a dry basis (\% dry weight) of different mushroom samples.

\begin{tabular}{|c|c|c|c|c|c|c|}
\hline \multirow{2}{*}{\multicolumn{2}{|c|}{ Sources of Fruiting Bodies }} & \multicolumn{5}{|c|}{ \% Dry Weight * } \\
\hline & & Ash & Protein & Fat & Fiber & Carbohydrate \\
\hline Natural sample & & $9.59 \pm 0.30 \mathrm{a}$ & $28.03 \pm 0.93 \mathrm{a}$ & $2.15 \pm 0.09 b$ & $6.67 \pm 0.38 \mathrm{a}$ & $50.86 \pm 1.19 b$ \\
\hline \multirow{6}{*}{ Cultivated sample } & $0 \mathrm{kV}$ & $9.55 \pm 0.22 \mathrm{a}$ & $18.80 \pm 0.53 b$ & $2.69 \pm 0.10 \mathrm{a}$ & $5.88 \pm 0.15 b$ & $57.21 \pm 0.97 \mathrm{a}$ \\
\hline & $20 \mathrm{kV}$ & $9.52 \pm 0.20 \mathrm{a}$ & $18.76 \pm 0.47 b$ & $2.66 \pm 0.13 \mathrm{a}$ & $5.92 \pm 0.30 \mathrm{~b}$ & $56.86 \pm 0.33 \mathrm{a}$ \\
\hline & $40 \mathrm{kV}$ & $9.53 \pm 0.35 \mathrm{a}$ & $18.58 \pm 0.54 b$ & $2.67 \pm 0.09 \mathrm{a}$ & $5.87 \pm 0.13 b$ & $56.96 \pm 0.89 \mathrm{a}$ \\
\hline & $60 \mathrm{kV}$ & $9.50 \pm 0.13 \mathrm{a}$ & $18.25 \pm 0.51 b$ & $2.63 \pm 0.15 \mathrm{a}$ & $5.84 \pm 0.17 \mathrm{~b}$ & $57.14 \pm 0.73 \mathrm{a}$ \\
\hline & $80 \mathrm{kV}$ & $9.48 \pm 0.36 \mathrm{a}$ & $18.40 \pm 0.54 b$ & $2.61 \pm 0.12 \mathrm{a}$ & $5.89 \pm 0.14 b$ & $56.73 \pm 0.56 \mathrm{a}$ \\
\hline & $100 \mathrm{kV}$ & $9.53 \pm 0.18 \mathrm{a}$ & $18.60 \pm 0.49 b$ & $2.70 \pm 0.10 \mathrm{a}$ & $5.90 \pm 0.10 \mathrm{~b}$ & $56.76 \pm 0.65 a$ \\
\hline
\end{tabular}

Additionally, the amounts of ash, carbohydrate, protein, fat, and fiber in cultivated fruiting bodies obtained from control and application of high-voltage pulse treatments were within the ranges described in previous reports. Accordingly, ash (6.7-50.29\%), carbohydrate (33.3-65.1\%), protein (14.0-36.3\%), fat (0.4-21.94\%), and fiber (3.1-38.11\%) contents were found in several edible ECM mushrooms obtained from natural habitats and in several other cultivated mushrooms $[4,45,48-53]$. Therefore, the P. spongiosus obtained from our cultivation process can be considered one of the cultivated mushrooms that would be highly suitable for the human diet.

\section{Conclusions}

Phlebopus spongiosus is a well-known edible ECM mushroom with high commercial value. In this study, the technological cultivation of P. spongiosus without a host plant was successfully achieved. Notably, it was determined that this mushroom is the second species within the genus Phlebopus that could be successfully cultivated on a commercial scale without a host plant. Accordingly, the application of high-voltage pulsed stimulation could improve the cultivation of this mushroom. An optimal voltage of $40 \mathrm{kV}$ was confirmed for efficient fruiting body induction and yield. Moreover, high-voltage pulsed stimulation had no effect on the proximate composition of the obtained fruiting bodies. The outcomes of this study will provide researchers with valuable information with regard to the largescale industrial production of this mushroom and cultivation yield improvement through high-voltage pulsed stimulation. However, a suitable nutrient composition of the substrate would be required in the future to achieve high nutritional content in the fruiting bodies and certain advantageous biological properties (antioxidant, antimicrobial and anticancer activities) of those cultivated fruiting bodies. 


\begin{abstract}
Author Contributions: Conceptualization: J.K., N.S. and S.L.; methodology: J.K. and N.S.; software: J.K.; validation: J.K., N.S. and S.L.; formal analysis: J.K.; investigation: J.K. and N.S.; resources: J.K. and N.S.; data curation: J.K., and N.S.; writing—original draft: J.K. and N.S.; writing-review and editing: J.K., N.S. and S.L.; supervision: J.K. and S.L. All authors have read and agreed to the published version of the manuscript.
\end{abstract}

Funding: This work was supported by Science and Technology Park, Chiang Mai University under Technology to Industry Convergence Program (181/2563), Thailand Science Research and Innovation (RGU6280009), Research Group for Renewable Energy, and Chiang Mai University, Thailand.

Institutional Review Board Statement: Not applicable.

Informed Consent Statement: Not applicable.

Data Availability Statement: Data sharing not applicable.

Acknowledgments: The authors are grateful to Jakarin Sirikulthorn for humidity control devices, Worawoot Aiduang for cultivation substrate preparation and Russell Kirk Hollis for the English correction of this manuscript.

Conflicts of Interest: The authors declare no conflict of interest.

\title{
References
}

1. Yun, W.; Hall, I.R. Edible ectomycorrhizal mushrooms: Challenges and achievements. Can. J. Bot. 2004, 82, 1063-1073. [CrossRef]

2. Perez-Moreno, J.; Guerin-Laguette, A.; Rinaldi, A.C.; Yu, F.; Verbeken, A.; Hernandez-Santiago, F.; Martinez-Reyes, M. Edible mycorrhizal fungi of the world: What is their role in forest sustainability, food security, biocultural conservation and climate change? Plants People Planet 2021, 3, 471-490. [CrossRef]

3. Susanna, B. Medicinal aspects of edible ectomycorrhizal mushrooms. In Edible Ectomycorrhizal Mushrooms; Zambonelli, A., Bonito, G., Eds.; Springer: Berlin, Germany, 2012; pp. 317-334.

4. Sanmee, R.; Dell, B.; Lumyong, P.; Izumori, K.; Lumyong, S. Nutritive value of popular wild edible mushroom from Northen Thailand. Food Chem. 2003, 82, 527-532. [CrossRef]

5. Zambonelli, A.; Bonito, G.M. Edible Ectomycorrhizal Mushroom; Springer: Berlin, Germany, 2012.

6. Hall, I.R.; Yun, W.; Amicucci, A. Cultivation of edible ectomycorrhizal mushrooms. Trends Biotechnol. 2003, 21, 433-438. [CrossRef]

7. Mortimer, P.E.; Karunarathna, S.C.; Li, Q.; Gui, H.; Yang, X.; Yang, X.; He, J.; Ye, L.; Li, H.; Sysouphanthong, P.; et al. Prized edible Asian mushrooms: Ecology, conservation and sustainability. Fungal Divers. 2012, 56, 31-47. [CrossRef]

8. Hirose, D.; Shirouzu, T.; Tokumasu, S. Host range and potential distribution of ectomycorrhizal basidiomycete Suillus pictus in Japan. Fungal Ecol. 2010, 3, 255-260. [CrossRef]

9. Yamanaka, T.; Ota, Y.; Konno, M.; Kawai, M.; Ohta, A.; Neda, H.; Terashima, Y.; Yamada, A. The host range of conifer-associatied Tricholoma matsutake, Fagaceae-assoviated T. bakamatsutake and T. fulvocastaneum are wider In Vitro than in nature. Mycologia 2014, 106, 397-406. [CrossRef] [PubMed]

10. Yamanaka, K.; Namba, K.; Tajiri, A. Fruit body formation of Boletus reticulatus in pure culture. Mycoscience 2000, 41, 189-191. [CrossRef]

11. Ohta, A. Production of fruit-bodies of a mycorrhizal fungus, Lyophyllum shimeji, in pure culture. Mycoscience 1994, 35, 147-151. [CrossRef]

12. Ohta, A. Fruit-body production of two ectomycorrhizal fungi in the genus Hebeloma in pure culture. Mycoscience 1998, 39, 15-19. [CrossRef]

13. Kumla, J.; Danell, E.; Lumyong, S. Improvement of yield for a tropical black bolete, Phlebopus portentosus, cultivation in northern Thailand. Mycoscience 2015, 56, 114-117. [CrossRef]

14. Kumla, J.; Suwannarach, N.; Lumyong, S. A new report on edible tropical bolete, Phlebopus spongiosus in Thailand and its fruiting body formation without the need for a host plant. Mycobiology 2020, 48, 263-275. [CrossRef] [PubMed]

15. Chuankid, B.; Schrey, H.; Thongbai, B.; Raspé, O.; Arold, N.; Hyde, K.D.; Stadler, M. Secondary metabolites of Phlebopus species from northern Thailand. Mycol. Prog. 2020, 19, 1525-1536. [CrossRef]

16. Pham, N.; Shimizu, K.; Takahashi, H.; Suzuki, A.; Fukiharu, T.; Le, B. Phlebopus spongiosus sp. nov. (Boletales, Boletinellaceae) with a sponge-like tissue. Mycotaxon 2012, 119, 27-34. [CrossRef]

17. Le, T.T.N.; Phan, M.H.; Tran, C.H.; Bul, V.T.; Pham, N.D.H.; Duong, H.X. Mycelial cultivation of Phlepobus spongiosus, an edible ectomycorrhizal mushroom in southern Vietnam. J. Sci. Ho Chi Minh City Open Univ. 2017, 7, 14-21.

18. Heinemann, P.; Rammeloo, J. Observations sur le genre Phlebopus (Boletineae). Mycotaxon 1982, 15, $384-404$.

19. Zhang, C.; He, M.; Liu, J.; Xu, X.; Cao, Y.; Gao, F.; Fang, Y.; Wang, W.; Wang, Y. Brief introduction to a unique edible boletePhlebopus portentosus in southern China. J. Agric. Sci. Technol. B 2017, 7, 386-394.

20. Deschamps, J.R.; Moreno, G. Phlebopus bruchii (Boletales): An edible fungus from Argentina with possible commercial value. Mycotaxon 1999, 72, 205-213.

21. Lumyong, S.; Sanmee, R.; Lumyong, P. Is large scale cultivation of boletes possible? Opera Mycol. 2007, 1, 4-37. 
22. Ji, K.P.; Cao, Y.; Zhang, C.X.; He, M.X.; Liu, J.; Wang, W.B.; Wang, Y. Cultivation of Phlebopus portentosus in southern China. Mycol. Prog. 2011, 10, 293-300. [CrossRef]

23. Sanmee, R.; Lumpong, P.; Bell, D.; Lumyong, S. In vitro cultivation and fruit body formation of the black bolete, Phlebopus portentosus, a popular edible ectomycorrhizal fungus in Thailand. Mycoscience 2010, 51, 15-22. [CrossRef]

24. Bellettini, M.B.; Fiorda, F.A.; Maieves, H.A.; Teixeira, G.L.; Avila, S.; Hornung, P.S.; Junior, A.M.; Ribani, R.H. Factors affecting mushroom Pleurotus spp. Saudi J. Biol. Sci. 2019, 26, 633-646. [CrossRef]

25. Takaki, K.; Miyamoto, K.; Takaki, K.; Takahasi, K. Development of compact high-voltage power supply for stimulation to promote fruiting body formation in mushroom cultivation. Materials 2018, 11, e2471.

26. Takaki, K.; Yamazaki, N.; Mukaigawa, S.; Fujiwara, T.; Kofujita, H.; Takahasi, K.; Narimatsu, M.; Nagane, K. Effect of pulsed high-voltage stimulation on Pholiota nameko mushroom yield. Acta Phys. Pol. A 2009, 6, 953-956. [CrossRef]

27. Ibrahim, R.; Boon, L.S.; Mazidi, M.N.I.H.; Yaacob, N.D. Effects of electrical shock and blue LED treatments on the growth, yield and quality of grey oyster mushrooms (Pleurotus sajor-caju). IOP Conf. Ser. Mater. Sci. Eng. 2020, 932, e012003. [CrossRef]

28. Hiramori, C.; Koh, K.; Kurata, S.; Ueno, Y.; Gamage, S.; Huang, P.; Ohga, S. Cultivation of Flammulina velutipes on modified substrate using fermented apple pomace. Adv. Microbiol. 2017, 7, 719-728. [CrossRef]

29. Langer, I.; Krpata, D.; Peintner, U.; Wenzel, W.W.; Schweiger, P. Media formulation influences in vitro ectomycorrhizal synthesis on the European aspen Populus tremula L. Mycorrhiza 2008, 18, 297-307. [CrossRef] [PubMed]

30. AOAC. Official Methods of Analysis of AOAC International, 16th ed.; AOAC International: Gaithersburg, MD, USA, 1996.

31. Salmones, D.; Gaitan-Hernandez, R.; Mata, G. Cultivation of Mexican wild strains of Agaricus bisporus, the button mushroom, under different growth conditions In Vitro and determination of their productivity. Biotechnol. Agron. Soc. Environ. 2018, 22, 45-53.

32. Martos, E.T.; Zied, D.C.; Junqueira, P.P.G.; Rinker, D.L.; Da Silva, R.; Toledo, R.C.C.; Dias, E.S. Casing layer and effect of primordia induction in the production of Agaricus subrufescens mushroom. Agric. Nat. Resour. 2017, 51, 231-234. [CrossRef]

33. Kumla, J.; Bussaban, B.; Suwannarach, N.; Lumyong, S.; Danell, E. Basidiome formation of an edible wild, putatively ectomycorrhizal fungus, Phlebopus portentosus without host plant. Mycologia 2012, 104, 597-603. [CrossRef]

34. Yang, R.H.; Bao, D.P.; Guo, T.; Li, Y.; Ji, G.Y.; Ji, K.P.; Tan, Q. Bacterial profiling and dynamic succession analysis of Phlebopus portentosus casing soil using Miseq sequencing. Front. Microbiol. 2019, 10, e1927. [CrossRef]

35. Carrasco, J.; Tello, M.L.; Perez, M.; Preston, G. Biotechnological requirement for the commercial cultivation of macrofungi: Substrate and casing layer. In Biology of Macrofungi; Singh, B., Lallawmsanga, P.A., Eds.; Springer: Basel, Switzerland, 2018; pp. 159-175.

36. Roshita, I.; Nurfazira, K.M.P.; Fern, C.S.; Ain, M.S.N. Electrical stimulation in white oyster mushroom (Pleurotus florida) production. AIP Conf. Proc. 2017, 1885, e020053.

37. Takaki, K.; Yoshida, K.; Saito, T.; Kusaka, T.; Yamaguchi, R.; Takahasi, K.; Sakamoto, Y. Effect of electrical stimulation on fruit body formation in cultivating mushrooms. Microorganisms 2014, 2, 58-72. [CrossRef]

38. Norarat, R.; Thipprasert, W.; Mikhamlueang, C.; Wanmanee, T.; Nanta, N.; Srijumpa, N. Effects of high voltage stimulation and oxygen rich fine bubble (FB) water on cultivated shiitake mushroom in Thailand. Int. J. Plasma Environ. Sci. Technol. 2019, 12, 69-73.

39. Islam, F.; Ohga, S. The response of fruit body formation on Tricholoma matsutake in situ condition by applying electric pulse stimulator. ISRN Agron. 2012, 2012, e462724. [CrossRef]

40. Takaki, K.; Takahashi, K.; Sakamoto, Y. High-Voltage Methods for Mushroom Fruit-Body Developments. In Physical Methods for Stimulation of Plant and Mushroom Development; El-Esawi, M.A., Ed.; IntechOpen: London, UK, 2018; pp. 95-113.

41. Kaneko, S.; Yamamoto, M.; Nakashima, Y.; Jitsufuji, Y. Studies on electrical stimulation on Lentinula edodes bed log. Bull. Fukuoka-Ken For. Exp. Stn. 1987, 33, 1-33.

42. Kudo, S.; Mitobe, S.; Yoshimura, Y. Electric stimulation multiplication of Lentinulus edodes. J. Inst. Electrost. Jpn. 1999, 23, 186-190.

43. Ohga, S.; Iida, S. Effect of electric impulse on sporocarp formation of ectomycorrhizal fungus Laccaria laccata in Japanese red pine plantation. J. For. Res. 2001, 6, 37-41. [CrossRef]

44. Ohga, S.; Cho, N.S.; Li, Y.; Royse, D.J. Utilization of pulsed power to stimulate fructification of edible mushroom. Mushroom Sci. 2004, 16, 343-352.

45. Hao, H.T.; Wang, C.L.; Wang, C.H. The effects of different substrates on the growth, yield, and nutritional composition of two oyster mushrooms (Pleurotus ostreatus and Pleurotus cystidiosus). Mycobiology 2015, 43, 423-434.

46. Sebaaly, Z.E.; Assadi, F.; Sassine, Y.N.; Shaban, N. Substrate types effect on nutrition composition of button mushroom (Agaricus bisporus). Agric. For. 2019, 65, 73-80.

47. Gupta, A.; Sharma, S.; Kumar, A.; Alam, P.; Ahmad, P. Enhancing nutritional contents of Lentinus sajor-caju using residual biogas slurry waste of detoxified mahua cake mixed with wheat straw. Front. Microbiol. 2016, 7, e1529. [CrossRef] [PubMed]

48. Kumla, J.; Hobbie, E.A.; Suwannarach, N.; Lumyong, S. The ectomycorrhizal status of a tropical black bolete, Phlebopus portentosus, assessed using mycorrhizal synthesis and isotopic analysis. Mycorrhiza 2016, 26, 333-343. [CrossRef] [PubMed]

49. Kumla, J.; Suwannarach, N.; Tanruean, K.; Lumyong, S. Comparative evaluation of chemical composition, phenolic compounds, and antioxidant and antimicrobial activities of tropical black bolete mushroom using different preservation methods. Foods 2021, 10, 781. [CrossRef] [PubMed] 
50. Agahar-Murugkar, D.; Subbulakshmi, G. Nutritional value of edible wild mushrooms collected from the Khasi hills of Meghalaya. Food Chem. 2005, 89, 599-603. [CrossRef]

51. Adejumo, T.O.; Awosanya, O.B. Proximate and mineral composition of four edible mushrooms species from south western Nigeria. Afr. J. Biotechnol. 2005, 4, 1084-1088.

52. Chittaragi, A.; Naika, R.; Vinayaka, K.S. Nutritive value of few wild mushrooms from the western Ghats of Shivamogga district, Karnataka, India. Asian J. Pharm. Clin. Res. 2014, 7, 50-53.

53. Srikram, A.; Supapvanich, S. Proximate compositions and bioactive compounds of edible wild and cultivated mushrooms from Northeast Thailand. Agric. Nat. Resour. 2016, 50, 432-436. [CrossRef] 